\title{
Thyroid Hormone Receptor and Receptor-Related RNA Levels in Developing Rat Brain
}

\author{
DANIEL NORTH AND DELBERT A. FISHER \\ Department of Pediatrics, UCLA Medical Center, Torrance, California 90509
}

\begin{abstract}
The proto-oncogene c-erbA and its analogues are genes that encode thyroid hormone receptors. In rats, at least two loci have been identified by their homology to c-erbA. Each locus can produce at least two distinct mRNA species via RNA processing. However, one of those transcripts, r-erbA $\alpha$-2, does not yield a triiodothyronine (T3)binding protein when translated in vitro. Proper development of the rat brain is thyroid hormone-dependent during the perinatal period and there is a documented increase in brain nuclear T3-binding capacity during that time. By hybridizing cDNA probes specific to various rat erbA-like transcripts with RNA extracted from developing rat brain, we sought changes in thyroid hormone receptor mRNA levels that correspond with changes in T3-binding capacity in rat brain during the perinatal period. Three mRNA of the erbA family showed variations in relative abundance during brain development. Oddly, r-erbA $\alpha-2$, a variant that does not code for a T3-binding protein, was the most abundant erbA-like RNA to correlate with the reported changes in T3-binding capacity. The message for rat $r$ $\operatorname{erbA} \alpha-1$ that encodes a functional $\mathrm{T} 3$ receptor also varies with T3-binding capacity but at a level that is at least 8 fold lower than the r-erbA $\alpha-2$ message. The level of rat $\operatorname{erbA} \beta-1$ message also varies in rat brain during the perinatal period but not in a way that correlates with changes in T3-binding capacity. (Pediatr Res 28: 622-625, 1990)
\end{abstract}

\section{Abbreviations}

T3, triiodothyronine

SSC, sodium chloride, sodium citrate

SSPE, sodium chloride, sodium phosphate, EDTA

Thyroid hormones play a active role in both the development and adult metabolism of a number of vertebrate species, but the developmental and adult roles of thyroid hormones are quite different. Hypothyroidism during development is manifested by neurologic and growth abnormalities. In contrast, hypothyroidism in the adult produces only metabolic alterations and there is little effect on brain function. The mechanism(s) for the differing actions of thyroid hormones in developing and adult brain remains obscure. Although most biochemical studies of thyroid hormone nuclear receptors suggest that the receptors in developing brain are similar to those in adult brain (1), recent evidence in both humans $(2-4)$ and rats $(5,6)$ indicates a genetic potential to produce at least two types of thyroid hormone nuclear receptors. In rats, the two types of receptor genes have been designated r-erbA $\alpha$ and r-erbA $\beta$. Posttranscriptional modification of the

Received April 17, 1990, accepted August 3, 1990

Correspondence and reprint requests: Daniel North, Ph.D., RB-1 Harbor-UCLA Medical Center, 1000 W. Carson Street, Torrance, CA 90509.

Supported by National Institutes of Health Grants HD-04270 and HD-07013.
RNA from these two loci generate additional diversity. The terms TR- $\alpha$ and TR- $\beta$ have also been used to describe erbA analogues. However, not all of the processed transcripts code for T3-binding receptors, making the TR designation misleading. In adults, the various mRNA species predominate in different tissues: r-erbA $\alpha$ 1 in skeletal muscle and brown fat (7); r-erbA $\alpha-2$ in brain (7); r$\operatorname{erbA} \beta-1$ in liver and kidney (6); and $r-\operatorname{erbA} \beta-2$, found only in pituitary (8).

Several investigators (9-11) have shown significant ontogenic variation in T3-nuclear receptor binding capacity in rat brain tissue. T3 binding is present during the later period of in utero development, increases in the neonatal period, and falls to adult levels by the time the rat is $20 \mathrm{~d}$ old ( $42 \mathrm{~d}$ postconception). To correlate these data with receptor message levels, we characterized the ontogenesis of $\mathrm{r}-\mathrm{erb} A \alpha-1, \mathrm{r}-\operatorname{erb} A \alpha-2$, and $\mathrm{r}$-erbA $\beta-1$ RNA levels in developing rat brain. We observed that rat erbA $\alpha$ 2 RNA is the most abundant message species to show variations that correlate with changes in nuclear T3-binding capacity. Oddly, although this mRNA codes for a thyroid hormone receptor-like DNA-binding protein, the protein does not bind T3 (7, 12). Messages capable of encoding functional T3-binding proteins also were found in developing brain tissue. The rat r-erbA $\alpha$ 1 mRNA also varies with T3-binding capacity but at an 8-fold lower level than the non-T3-binding variant. Rat $\operatorname{erbA} \beta$ message rises during the postnatal period but, unlike binding capacity, the level of $\mathrm{r}$-erbA message remains elevated in adults.

\section{MATERIALS AND METHODS}

Sprague-Dawley rats were obtained from Simonson Laboratories (Gilroy, CA). Date-bred rats from the same source provided the fetal animals used in the study. The animals were maintained in accordance with the NIH Guide for the Care and Use of Laboratory Animals. After decapitation, rat brain tissues were removed and quickly frozen in a bath of liquid nitrogen. For each age group, brains were collected from at least four individual animals and pooled. The frozen brains were stored at $-70^{\circ} \mathrm{C}$. Before RNA extraction, the pooled brain tissue was again placed in liquid nitrogen and ground into a coarse powder with a mortar and pestle. RNA was extracted from $100 \mathrm{mg}$ of the powder using RNAzol (Cinna-Biotecx, Friendswood, TX). Each extraction yielded about $100 \mu \mathrm{g}$ of RNA as assayed by absorbance at 260 nm.

To produce slot blots, $10 \mu \mathrm{g}$ of RNA was applied to nylon membranes (MSI, Westborough, MA) using essentially the procedures of Kafatos et al. (13). The RNA was dissolved in $400 \mu \mathrm{L}$ of $5.1 \mathrm{M}$ formaldehyde, $7.5 \times \mathrm{SSC}$. The samples were incubated $15 \mathrm{~min}$ at $65^{\circ} \mathrm{C}$ and $400 \mu \mathrm{L}$ were loaded to each slot and washed with an additional $400 \mu \mathrm{L} 10 \times$ SSC. For Northern blots. $12-15$ $\mu \mathrm{g}$ of RNA were denatured with glyoxal (50\% DMSO, $1 \mathrm{M}$ glyoxal, $10 \mathrm{mM} \mathrm{NaH} \mathrm{PO}_{4}, \mathrm{pH} 7.0$ ) for $15 \mathrm{~min}$ at $50^{\circ} \mathrm{C}$ and electrophoresed on $1 \%$ agarose gels as described by Maniatis (14). Ribosomal RNA bands were visualized by staining the gels for $15 \mathrm{~min}$ in $0.5 \mu \mathrm{g} / \mathrm{mL}$ ethidium bromide and viewing on a UV transilluminator. The RNA was blotted for $12-20 \mathrm{~h}$ to nylon 
membranes with $20 \times$ SSC. These conditions were sufficient to transfer both ethidium-stained ribosomal RNA bands out of the gels. All blots were baked for $2 \mathrm{~h}$ at $80^{\circ} \mathrm{C}$ before hybridization.

Four erbA analogue probes were used in these experiments (Fig. 1). The probe for r-erbA $\alpha$ and its variants is a 500-bp PvulI fragment of pRBEA12 as described by Thompson et al. (5). The r-erbA $\beta$ probes (6) consisted of a 1442-bp PstI fragment (probe C) that contained the entire 1371-bp r-erbA $\beta$ coding region and a 797-bp PstI/HpaII fragment (probe D) that did not contain the $3^{\prime}$ sequence having high homology with rat $\mathrm{r}-\operatorname{erbA} \alpha-1$. The oligonucleotide probe (B) codes for amino acids 375-384 at the $\mathrm{C}$ terminus of the rat $\mathrm{r}$-erbA $\alpha-1$ protein. A 5th probe consisted of a 1200-bp BglI fragment of rat $\beta$-actin (15).

DNA probes (A, C, D, and rat $\beta$-actin) were labeled using ${ }^{32} \mathrm{P}$ deoxy-cytidine triphosphate, random primers, and Klenow fragment (Multiprime, Amersham, Arlington Heights, IL). Typically, $50 \mathrm{ng}$ of fragment yielded $4-8 \times 10^{7}$ of precipitable counts, which were used for individual hybridizations. The oligonucleotide probe (B) was $5^{\prime}$ end-labeled with $\gamma_{-}{ }^{32} \mathrm{P}$ ATP and polynucleotide kinase (New England Nuclear, Boston, MA); typically, $32 \mathrm{pmol}$ of the oligonucleotide was labeled to $2-4 \times 10^{6} \mathrm{cpm} / \mathrm{pmol}$ and the entire yield was used in hybridizations.

Hybridization and washing conditions were those described by the membrane manufacturer (MSI) for perfect hybrids. Prehybridizations were $4 \mathrm{~h}$ at $42^{\circ} \mathrm{C}$ in $50 \%$ formamide, $5 \times$ Denhardt's, $5 \times$ SSPE, $0.1 \%$ SDS, and $200 \mu \mathrm{g} / \mathrm{mL}$ carrier DNA. Hybridizations were overnight at $42^{\circ} \mathrm{C}$ in $50 \%$ formamide, $5 \times$ Denhardt's, $5 \times$ SSPE, $0.1 \%$ SDS, $5 \%$ dextran sulfate, and $200 \mu \mathrm{g} / \mathrm{mL}$ carrier DNA. Hybridization was followed by three washes in $2 \times$ SSC, 5 min each at $22^{\circ} \mathrm{C}$; two washes in $2 \times \mathrm{SSC}$ and $0.5 \%$ SDS, 15 min each at $50^{\circ} \mathrm{C}$; and two washes in $0.1 \times \mathrm{SSC}$ for $5 \mathrm{~min}$ each at $22^{\circ} \mathrm{C}$.

Autoradiographs were made by using the blots to expose Kodak X-Omat film at $-70^{\circ} \mathrm{C}$. Densitometry was performed and analyzed using a BioRad model 620 video densitometer and 1DPACK software (Bio Rad Laboratories, Richmond, CA).

\section{RESULTS}

RNA was extracted from the brains of rats ranging in age from 19 to more than $80 \mathrm{~d}$ postconception (birth occurs at 22 days

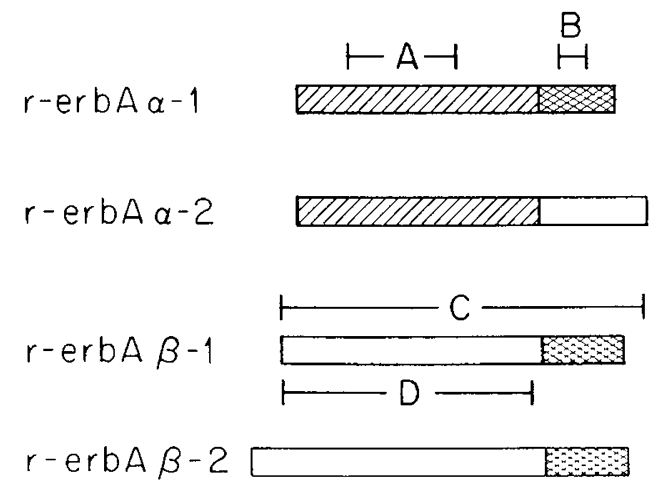

Fig. 1. A comparison of the rat erbA $\alpha$ and $\mathrm{r}-\operatorname{erbA} \beta$ messages and the regions to which probes are made. Rat $\operatorname{erbA} \alpha-1$ and a variant, r-erbA $\alpha$ 2 , are shown at the top of the diagram. At the bottom are the rat $\operatorname{erbA} \beta$ messages. The rat erbA $\alpha$ messages are generated by alternative splicing of a $5^{\prime}$ region (slanted lines) to various $3^{\prime}$ ends. In vitro translation of the rat $\mathrm{r}$-erbA $\alpha-1$ message with its particular $3^{\prime}$ end (crosshatch) yields a protein that binds $\mathrm{T} 3$. Both rat erbA $\beta$ messages can be translated in vitro to produce proteins that bind T3. In vitro translation of the rat r-erbA $\alpha$ 2 variants does not generate proteins that bind T3. The $3^{\prime}$ ends of the rat erbA $\beta$ messages code for 46 amino acids that are identical to the amino acids that are coded for by the $3^{\prime}$ end of rat $\operatorname{erbA} \alpha-1$. Because of differential codon usage, probe $B$ is mismatched at four of 30 bases in the $3^{\prime}$ end of $\mathrm{r}$-erbA $\beta$. Probe $\mathrm{C}$ is $1442 \mathrm{bp}$ in length and includes all 1371 bp of the rat erbA $\beta-1$ coding region plus a small amount of leader and trailer. Probe $D$ is $797 \mathrm{bp}$ and contains only the regions unique to rat $\operatorname{erbA} \beta$. postconception). Equal amounts of RNA from each age were applied to a nylon membrane using a slot blotter. The membrane was probed with probe A (Fig. 1), which contains a 500-bp central fragment that is common to all of the rat $\operatorname{erbA} \alpha$ messages. Autoradiographs were produced and relative amounts of message were quantified using densitometry. Figure 2 shows the results of the densitometry of one of the slot blots and is representative of data from a number of similar slot blot and Northern blot experiments. Relative to total RNA, the amount of RNA transcribed from the erbA $\alpha$ gene rises quickly during the perinatal period, remains at elevated levels from $25-37 \mathrm{~d}$ postconception (3-15 d postnatal), and falls to adult levels after d 40 postconception ( $18 \mathrm{~d}$ postnatal). The overall change is 2.5 -fold. The agedependent variation of the relative amount of mRNA coding for rat $\operatorname{erbA} \alpha$ is strikingly similar to the age-dependent variation in the relative amount of $\mathrm{T} 3$ receptor found in rat brain as demonstrated previously by several investigators (9-11).

Internal standards, such as an RNA species whose concentration remains constant with time, are difficult to obtain in ontogeny studies. Although the level of rat $\beta$-actin mRNA is not constant during rat brain development, it clearly follows a different pattern than was seen with the r-erbA $\alpha$ probe (Fig. 2). The variations in the abundance of $\beta$-actin RNA in developing rat brain tissue, shown in Figure 2, are similar to those reported by others $(16,17)$. Northern blots were prepared from total RNA. For these experiments, it was possible to visualize RNA loading inequities in the gels by comparing the intensities of ethidium bromide-stained ribosomal RNA bands before blotting.

To produce the Northern hybridizations shown in Figure 3, $12 \mu \mathrm{g}$ of RNA extracted from rat brain tissue at the indicated ages were electrophoresed on a $1 \%$ agarose gel. Ethidium bromide staining of the gel is shown in Figure $3 \mathrm{~A}$. The gel was blotted, hybridized with a probe common to the r-erbA species (probe A), and autoradiographed. The autoradiograph in Figure $3 B$ indicates visually what is shown graphically in Figure 2; the relative amount of RNA that hybridizes with the r-erbA $\alpha$ probe (probe A) is low before birth, peaks near postconception d 31, and falls to adult levels after postconception d 40 . More importantly, densitometry of the autoradiograph in Figure $3 B$ shows that the quantitative data presented in Figure 2 is due to hybridization with a unique $2.6-\mathrm{kb}$ RNA species, the size reported for

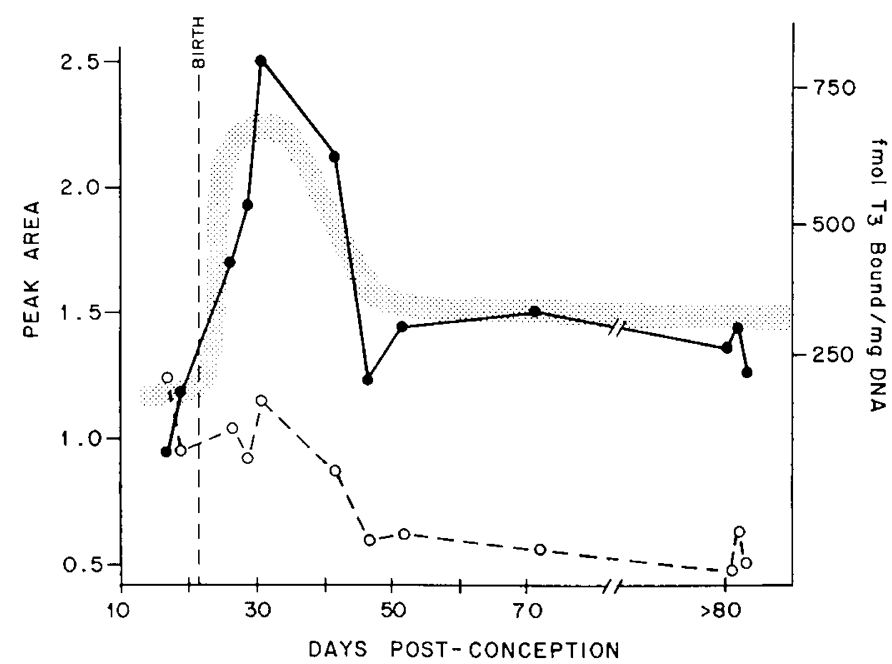

Fig. 2. Variations of rat $r$-erbA $\alpha$ message in rat brain as a function of age. Ten $\mu \mathrm{g}$ of total rat brain RNA collected at the indicated ages were immobilized on a nylon filter using a slot blot apparatus. The blot was then hybridized with the rat $\operatorname{erbA} \alpha$ (A) probe. Densitometry was performed on the resulting autoradiograph and peak areas (solid line) were plotted as a function of age postconception. For comparison, changes in T3-binding capacity were compiled from refs. 6-8 and plotted (shaded area). To generate the lower dashed line, the blot was washed, hybridized with a rat $\beta$-actin probe, and autoradiographed again. 


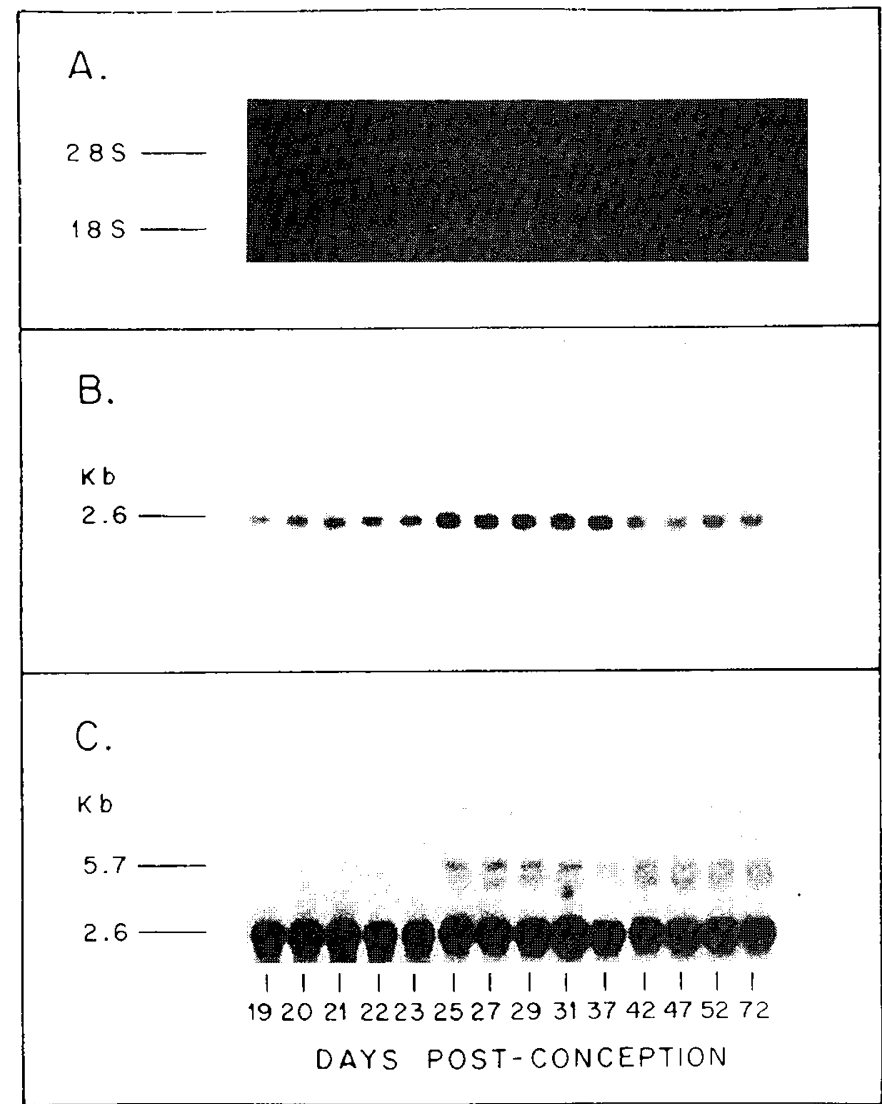

Fig. 3. Hybridization of the rat $\operatorname{erbA} \alpha$ (A) probe to a Northern blot of rat brain RNA collected at various ages. Twelve $\mu \mathrm{g}$ of total rat RNA collected at the indicated ages were electrophoresed on a $1 \%$ agarose gel, blotted to a nylon filter, and hybridized with the rat $\operatorname{erbA} \alpha(\mathrm{A})$ probe. Panel $A$ shows the ethidium bromide-stained gel immediately before blotting. Panel $B$ shows the autoradiograph generated after a 42 -h exposure and panel $C$ shows the autoradiograph resulting from a 1 -wk exposure.

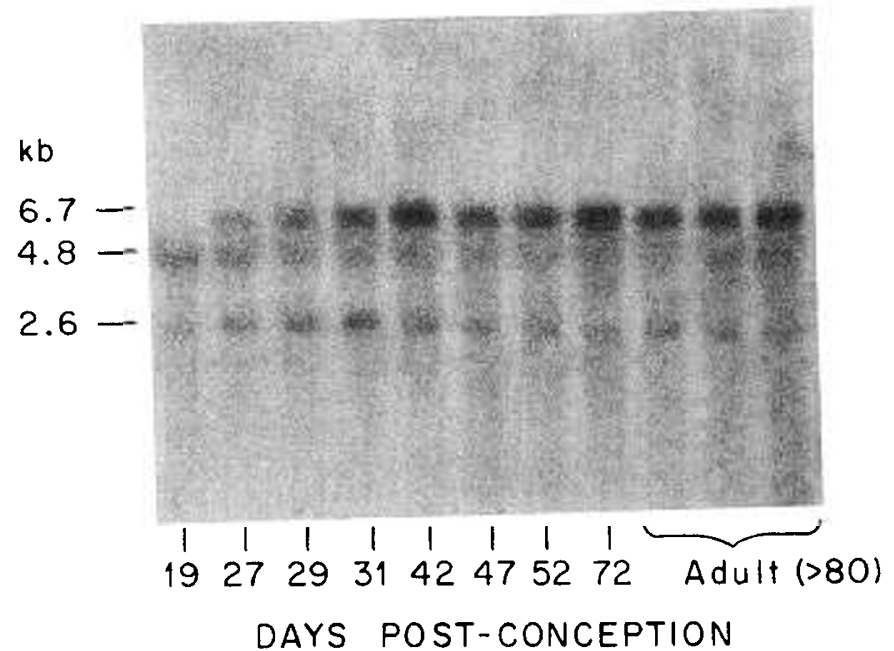

Fig. 4. A comparison of the relative levels of the rat $\operatorname{erbA} \beta$ message in rat brain at various ages. Twelve $\mu \mathrm{g}$ of total rat brain RNA collected at the indicated ages were electrophoresed on a $1 \%$ agarose gel, blotted to a nylon filter, and hybridized with the rat erbA $\beta$ probe (probe D). The autoradiograph is shown.

rat $\mathrm{r}$-erbA $\alpha$-2 message (12). Longer exposures of the same blot (Fig. $3 C$ ) make it possible to distinguish a larger, 5.7-kb, r-erbA $\alpha$ 1 band. Although attenuated, variations in the $5.7-\mathrm{kb}$ band mimicked changes in the $2.6-\mathrm{kb}$ band. Densitometry of the

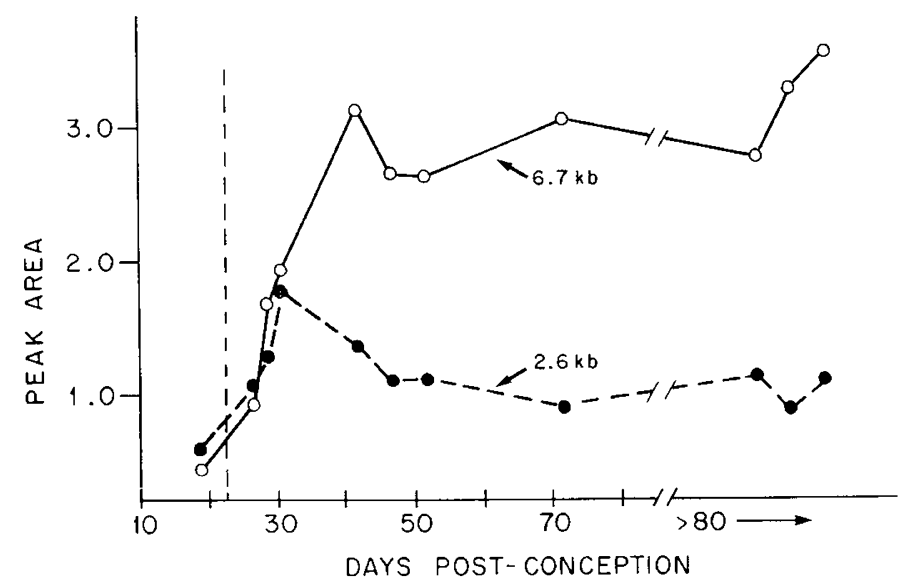

Fig. 5. Densitometry of the Northern blot shown in Figure 4. The peak areas of the 2,6- and $6.7-\mathrm{kb}$ bands are plotted as a function of the age at which the RNA was collected.

autoradiograph in Figure $3 C$ shows that in all lanes, the $2.6-\mathrm{kb}$ message has at least 8 -fold more hybridizable material than the $5.7-\mathrm{kb}$ band. Because the intensity of the $2.6-\mathrm{kb}$ band is near saturation, the $8: 1$ ratio of $\mathrm{r}-\mathrm{erbA} \alpha-2$ to $\mathrm{r}-\mathrm{erbA} \alpha-1$ represents a minimum value.

In adult rat brain, the $2.6-\mathrm{kb}$ message results from hybridization to r-erbA $\alpha-2$, which does not encode a T3-binding protein (12). However, $2.6 \mathrm{~kb}$ is large enough to contain the coding region of r-erbA $\alpha-1$, and variations in the amount of the message correspond well with changes in T3-binding capacity. To determine whether the most abundant species, the $2.6-\mathrm{kb}$ message, contained the coding region necessary to produce a functional T3-binding protein in perinatal rats, an oligonucleotide probe specific to the T3-binding domain was obtained (Fig 1, probe B). The blot shown in Figure 3 was washed and reprobed with the oligonucleotide. The results were consistent with what has been seen in adult brain tissue; there was no hybridization to the 2.6$\mathrm{kb}$ band but there was hybridization to the $5.7-\mathrm{kb}$ band (data not shown).

Levels of RNA transcripts from the rat $\operatorname{erbA} \beta$ gene also were assessed by probing Northern blots. Two probes were generated. Probe $C$ was 1442 bp in length and contained the entire 1371bp rat erbA $\beta-1$ coding region. Probe $\mathrm{D}$ was shorter (797 bp) and eliminated the $3^{\prime}$ regions that have high homology to rat $\operatorname{erbA} \alpha$ 1. Both probes gave identical banding patterns on Northern blots of rat brain tissue. Figure 4 shows the autoradiograph generated by probing a rat brain ontogeny Northern blot with probe $\mathrm{C}$. The $6.7-\mathrm{kb}$ band is the size of the reported rat erbA $\beta-1$ message (6). The amount of message increases after birth until $37 \mathrm{~d}$ postconception and remains at this plateau level in adults. Although we used high-stringency wash conditions that were optimized for perfect hybrids, a small amount of cross-hybridization with two abundant RNA species is visible in Figure 4. The 4.8$\mathrm{kb}$ band is identical in size and appearance to the $28 \mathrm{~S}$ ribosomal RNA band and is likely a result of hybridization to ribosomal RNA. Interestingly, there is also a $2.6-\mathrm{kb}$ band, which is most intense in 9 -d-old rats ( $31 \mathrm{~d}$ postconception). The $2.6-\mathrm{kb}$ band is probably a result of cross-hybridization with the abundant $\mathrm{r}$ $\operatorname{erbA} \alpha-2$ RNA and shows the same pattern of variation. Densitometry was used to quantify the relative amounts of hybridization to the $6.7-$ and $2.6-\mathrm{kb}$ bands and is presented in Figure 5.

\section{DISCUSSION}

We examined total rat brain RNA for the presence of three different erbA-like species. Rat $\operatorname{erb} A \alpha-1$ and $\mathrm{r}-\operatorname{erb} A \beta-1$ encode thyroid hormone receptors; $\operatorname{erbA} \alpha-2$ codes for a protein with the same DNA-binding region as r-erbA $\alpha-1$, but the protein does not bind T3. A combined analysis of both slot blots and Northern 
blots showed that during rat brain development, the r-erbA $\alpha-2$ message is the most abundant message to show level changes that correspond with changes in T3-binding capacity during the same period (Fig. 2). The message for r-erbA $\alpha-1$ also changes with T3-binding capacity, but at a level that is at least 8-fold less than r-erbA $\alpha$-2. Mitsuhashi and Nikodem (18), performing similar experiments with rats of four different ages, estimated the ratio of r-erbA $\alpha-1$ to r-erbA $\alpha-2$ in rat brain to be 1:6. They also observed a postnatal increase in the level of $\mathrm{r}-\operatorname{erbA} \alpha-1(\mathrm{rTR} \alpha)$. However, although their data is suggestive of a postnatal increase in r-erbA $\alpha-2$ abundance, they report no increase. The reason(s) for this discrepancy relative to our studies is not clear. One possibility is a difference in the way that the RNA was prepared. The experiments described here used total RNA, whereas Mitsuhashi and Nikodem (18) used poly(A)+ RNA. It is possible that the postnatal increase we see results from an increase in $\operatorname{poly}(\mathrm{A})-\mathrm{r}-\mathrm{erb} \mathrm{A} \alpha-2$. A second explanation for the conflicting results is that different probes were used. One of our probes hybridized with all known r-erbA $\alpha$ variants and a second hybridized only with variants coding for T3 binding. Mitsuhashi and Nikodem (18), on the other hand, used a probe specific to the unique region of r-erbA $\alpha-2$ ( $\mathrm{r}-\mathrm{TR} \alpha \mathrm{VI}(\mathrm{II}))$ ). Our results could indicate the presence of additional $\mathrm{r}$-erbA $\alpha$ splicing variants. A third, 2.8-kb, r-erbA $\alpha$ splicing variant has been described recently in rat liver $(17,18)$, and others may exist.

Thyroid nuclear receptors also can be derived from translation of the rat erbA $\beta$ message. Through RNA processing, the initial transcript can produce two RNA species. Although both code for T3-binding receptors, $\mathrm{r}-\operatorname{erbA} \beta-2$ is found exclusively in the pituitary gland (8). The probe that was used for these experiments was common to both of the r-erbA $\beta$ transcripts. Before birth (22 d postconception), the brain tissue samples contained pituitary tissue. Thus, the low levels of $\mathrm{r}$-erbA $\beta$ transcripts seen in the fetal tissues result from both r-erbA $\beta-1$ and $\mathrm{r}-\operatorname{erb} A \beta-2$. Regardless of the source, the levels before birth were low. The $\operatorname{rerbA} \beta-1$ message abundance increases immediately after birth $(22 \mathrm{~d}$ postconception) to a peak at $37 \mathrm{~d}$ postconception. The message level then stabilizes and is maintained in adults. Although the rise in $\mathrm{r}-\operatorname{erbA} \beta$ message level and the rise in T3-binding capacity in rat brain coincide, T3-binding capacity decreases in adult rat brain, whereas the level of rat erbA $\beta-1$ message does not.

The highest concentrations of thyroid nuclear receptors in adult rat brain have been found in the amygdala, hippocampus, and cerebral cortex (19). The location and heterogeneity of nuclear thyroid receptor types within the developing brain remain unclear. Our data were obtained using whole brain in the fetus and cerebrum in postnatal samples. Limited studies of dissected neonatal rat brain suggest that changes in T3-binding capacity during development of the cerebrum are representative of whole brain (10). However, individual areas of the brain may have different distributions of receptor types, and receptor studies would not detect the r-erbA $\alpha-2$ protein. In both rat (19) and chick brain (20), neuronal cells generate nearly all of the T3binding capacity. T3 binding in glial elements is relatively reduced; in rat forebrain, greater than $90 \%$ of the T3-binding capacity was associated with neurons.

Three RNA species that encode thyroid hormone receptors or receptor-like proteins vary in abundance in rat brain during the perinatal period. Although it is possible that the production of one or more of the encoded proteins is not closely linked to message level, our results are consistent with the view that the $5.7-\mathrm{kb}$ r-erbA $\alpha-1$ RNA is responsible for most of the surge in $\mathrm{T} 3$-binding capacity in rat brain during the postnatal period. The $6.7-\mathrm{kb}$ r-erbA $\beta$ message also contributes to the postnatal increase in T3-binding capacity at a level that is maintained in adults. The receptor derived from rat erbA $\beta$ - 1 message may be of greatest importance after $50 \mathrm{~d}$ postconception when the level of r-erbA $\alpha$ 1 message subsides. Two groups of investigators $(21,22)$ have shown that the protein product of the r-erbA $\alpha-2$ message can bind to DNA at thyroid hormone receptor elements and inhibit the action of fully functional $\mathrm{T} 3$ receptors. Thus, it is possible that proteins resulting from the high levels of rat brain r-erbA $\alpha$ 2 message during the postnatal period may act competitively with T3-binding receptor proteins to modulate thyroid hormone responsive gene transcription.

\section{REFERENCES}

1. Oppenheimer JH, Schwartz HL, Mariash CN, Kinlaw WB, Wong NC, Freake HC 1987 Advances in our understanding of thyroid hormone action at the cellular level. Endocr Rev 8:288-308

2. Weinberger C, Giguere V, Hollenberg SM, Thompson C, Arriza J, Evans RM 1987 Human steroid receptors and erb-A gene products form a superfamily of enhancer-binding proteins. Clin Physiol Biochem 5:179-189

3. Benbrook D, Pfahl M 1987 A novel thyroid hormone receptor encoded by a cDNA clone from a human testis library. Science 238:788-791

4. Sakuri A, Nakai A, DeGroot LJ 1989 Expression of three forms of thyroid hormone receptor in human tissues. Mol Endocrinol 3:392-399

5. Thompson CC, Weinberger C, Lebo R, Evans RM 1987 Identification of a novel thyroid hormone receptor expressed in the mammalian central nervous system. Science 237:1610-1614

6. Murry MB, Zilz ND, McCreary NL, MacDonald MJ, Towle HC 1988 Isolation and characterization of rat cDNA clones for two distinct thyroid hormone receptors. J Biol Chem 263:12770-12777

7. Lazar MA, Hodin RA, Darling DS, Chin WW 1988 Identification of a rat cerbA alpha-related protein which binds deoxyribonucleic acid but does not bind thyroid hormone. Mol Endocrinol 2:893-910

8. Hodin RA, Lazar MA, Wintman BI, Darling DS, Koenig RJ, Larsen PR, Moore DD, Chin WW 1989 Identification of a thyroid hormone receptor that is pituitary-specific. Science 244:76-79

9. Perez-Castillo A, Bernal J, Ferreiro B, Pans T 1985 The early ontogenesis of thyroid hormone receptor in the rat fetus. Endocrinology 117:2457-2461

10. Schwartz HL, Oppenheimer JH 1978 Ontogenesis of 3,5,3'-triiodothyronine receptors in neonatal rat brain: dissociation between receptor concentration and stimulation of oxygen consumption by 3,5,3'-triiodothyronine. Endocrinology 103:943-948

11. Valcana T, Timiras PS 1978 Nuclear triiodothyronine receptors in the developing rat brain. Mol Cell Endocrinol 11:31-41

12. Mitsuhashi T, Tennyson GE, Nikodem VM 1988 Alternative splicing generates messages encoding rat c-erbA proteins that do not bind thyroid hormone. Proc Natl Acad Sci USA 85:5804-5808

13. Kafatos FC, Jones WC, Efstratiadis A 1979 Determination of nucleic acid sequence homologies and relative concentrations by a dot hybridization procedure. Nucleic Acids Res 7:1541-1552

14. Maniatis T 1982 Molecular cloning: a laboratory manual. Cold Spring Harbor Laboratory, Cold Spring Harbor, NY

15. Nudel U, Zakut R, Shani M, Neuman S, Levy Z, Yaffe D 1983 The nucleotide sequence of the rat cytoplasmic $\beta$-actin gene. Nucleic Acids Res 11:17591771

16. Safaei R, Fischer I 1989 Cloning of a cDNA encoding MAPIb in rat brain: regulation of mRNA levels during development. J Neurochem 52:18711879

17. Duman RS, Saito N, Tallman JF 1989 Development of $\beta$-adrenergic receptor and $G$ protein messenger RNA in rat brain. Mol Brain Res 5:289-296

18. Mitsuhashi T, Nikodem VM 1989 Regulation of expression of the alternative mRNAs of the rat a-thyroid hormone receptor gene. J Biol Chem 264:89008904

19. Ruel J, Faure R, Dussault JH 1985 Regional distribution of nuclear T3 receptors in rat brain and evidence for preferential localization in neurons. J Endocrinol Invest 8:343-348

20. Haidar MA, Dube S, Sarkar PK 1983 Thyroid hormone receptors of developing chick brain are predominantly in the neurons. Biochem Biophys Res Commun 112:221-227

21. Koenig RJ, Lazar MA, Hodin RA, Brent GA, Larsen PR, Chin WW, Moore DD 1989 Inhibition of thyroid hormone action by a nonhormone binding c-erbA protein generated by alternative mRNA splicing. Nature 337:659661

22. Sap J, Munoz A, Schmitt J, Stunnenberg H, Vennstrom B 1989 Repression of transcription mediated at a thyroid hormone response element by the v-erbA oncogene product. Nature 340:242-244 